\title{
Denudation and uplift of the Mawson Escarpment (eastern Lambert Graben, Antarctica) as indicated by apatite fission track data and geomorphological observation
}

\author{
F. Lisker, ${ }^{1}$ H. Gibson, ${ }^{2}$ C. J. Wilson, ${ }^{3}$ and A. Läufer ${ }^{4}$ \\ ${ }^{1}$ Universität Bremen, FB 5, Postfach 330440, 28334 Bremen, Germany (flisker@uni-bremen.de) \\ ${ }^{2}$ GeoIntrepid, Unit 2, 1 Male Street, Brighton, Victoria 3186, Australia \\ ${ }^{3}$ School of Earth Sciences, The University of Melbourne, Victoria 3010, Australia \\ ${ }^{4}$ Bundesanstalt für Geowissenschaften und Rohstoffe, Postfach 510153, 30631 Hannover, Germany
}

\begin{abstract}
Analysis of three vertical profiles from the southern Mawson Escarpment (Lambert Graben) reveals apatite fission track (AFT) ages ranging from $102 \pm 20$ to $287 \pm 23 \mathrm{Ma}$ and mean lengths of 12.2 to $13.0 \mu \mathrm{m}$. Quantitative thermal histories derived from these data consistently indicate onset of slow cooling below $110^{\circ} \mathrm{C}$ began sometime prior to $300 \mathrm{Ma}$, and a second stage of rapid cooling from paleotemperatures up to $\leq 100^{\circ} \mathrm{C}$ to surface temperatures occurred in the Late Cretaceous - Paleocene. The first cooling phase refers to Carboniferous - Jurassic basement denudation up to $5 \mathrm{~km}$ associated with the initial rifting of the Lambert Graben. The presence of the ancient East Antarctic Erosion Surface and rapid Late Cretaceous - Paleocene cooling indicate a second denudational episode during which up to $4.5 \mathrm{~km}$ of sedimentary cover rocks were removed, and that is likely linked to the Cretaceous Gondwana breakup between Antarctica and India and subsequent passive continental margin formation.
\end{abstract}

Citation: Lisker, F., , H. Gibson, C.J. Wilson, and A. Läufer (2007), Denudation and uplift of the Mawson Escarpment (eastern Lambert Graben, Antarctica) as indicated by apatite fission track data and geomorphological observation, in Antarctica: A Keystone in a Changing World - Online Proceedings of the 10th ISAES, edited by A.K. Cooper and C.R. Raymond et al., USGS Open-File Report 2007-1047, Short Research Paper 105, 6 p.; doi:10.3133/of2007-1047.srp105

\section{Introduction}

The Lambert Graben transects the metamorphic basement of the East Antarctic Craton perpendicular to the continental margin in the vicinity of Prydz Bay (Fig. 1). Hosting the largest glacial drainage system of the world, it also represents one of the largest rift systems of Antarctica. The western shoulder of the Lambert Graben is exposed for more than $700 \mathrm{~km}$. It consists of the northern Prince Charles Mountains (PCM), a group of nunataks around the Fisher Massif, and the southern PCM, and shows significant geomorphological differences. The northern PCM consist of mountainous massifs with partially spiky summits, while the Fisher Massif area comprises only small nunataks and ridges. The southern PCM expose a landscape of high peaks with altitudes up to $>3000 \mathrm{~m}$ a.s.l. in the west and lower, flat summits towards the Lambert Glacier in the east.

In contrast, the eastern rift shoulder of the Lambert Graben is represented only by a single, homogeneous landscape feature, the Mawson Escarmpent. The Mawson Escarpment is a $\sim 150 \mathrm{~km}$ long escarpment with a topographic offset, that partially exceeds a height of 1 $\mathrm{km}$, towards the Lambert Graben. It is covered by a flat erosion surface of regional extent (Wellmann \& Tingey, 1981) that gently declines towards the east (Fig. 2). Field evidence (effusion of $55 \mathrm{Ma}$ vesiculous eucritic rocks) indicates an early Cenozoic age of this "East Antarctic Erosion Surface".

Our knowledge of the long-term landscape evolution of the Lambert Graben depends very much on accessibility and geomorphological appearance of both shoulders of this rift structure. While there exist detailed thermochronological studies from the logistically less challenging northern PCM (Arne, 1994; Lisker et al., 2003), the landscape evolution of the southern graben segments and the eastern graben shoulder is largely unknown. This paper presents the first apatite fission track (AFT) data from the Mawson Escarpment with the aim to determine the timing and magnitude of maximum paleotemperatures, to derive burial depths, and to interpret the denudation history of the southern Mawson Escarpment. The low-temperature thermal, spatial and structural pattern of the southern Mawson Escarpment, together with data from the northern PCM and the Vestfold Hills and geomorphological indications, bear essential information about the timing, style and magnitude of rifting of the Lambert Graben, as well as the reactivation of rifting processes, the uniformity of the tectonic activity, and the mechanisms triggering the regional long-term landscape development.

\section{Geological overview}

The basement of the Lambert Graben is composed by a melange of Precambrian terranes of similar rheological behaviour. It comprises a broad spectrum of metamorphic rocks ranging from low-grade Archaean and early Proterozoic granitic basement and metasedimentary rocks in the southern PCM and the Mawson Escarpment to high-grade late Proterozoic granulites and charnockites in the north. These rocks underwent a multistage tectono-metamorphic history with granulitefacies events at 3000, 2500 and $1100 \mathrm{Ma}$ (e.g., Sheraton, 1984). Both Prydz Bay and the PCM were overprinted by a main metamorphic episode of Pan-African age (540-490 Ma/ e.g., Boger et al., 2002). 
The Phanerozoic geological history of the region is constrained only coarsely by thermochronological data and structural analyses since pre-Pliocene sedimentary deposits are confined to a single location within the northern PCM. There, the Permo-Triassic Amery Group, a $\sim 2 \mathrm{~km}$ thick fault bound continental sequence, crops out in the vicinity of Beaver Lake. The denudational history of the northern PCM was quantified on the basis of thermal history modelling of AFT data (Arne, 1994; Lisker et al., 2003). The cooling patterns indicate two denudation phases during the Phanerozoic. Minimum mid-late Palaeozoic denudation between 1.6 and $5.0 \mathrm{~km}$, which corresponds closely with the Gondwana sedimentation of the Amery Group, probably represents initial rifting in the Lambert Graben. The initiation of rifting was likely related to the formation of the ancestral Gamburtsev Mountains due to Variscan compression and substantial crustal thickening of the
East Antarctic Craton. A second rifting stage associated with crustal denudation of 1.0 to $4.5 \mathrm{~km}$ commenced in the Early Cretaceous. The Cretaceous pre-rift geothermal gradient increased from $19^{\circ} \mathrm{Ckm}^{-1}$ below the western part of the northern PCM to $29^{\circ} \mathrm{Ckm}^{-1}$ along the immediate graben shoulder. The Cretaceous denudation/ rifting stage in the northern PCM was probably related to the activity of the Kerguelen plume and the beginning of the Gondwana separation between India and Antarctica.

A similar thermal history has been reported from the Vestfold Hills at the intersection of Lambert Graben and passive continental margin (Lisker et al., 2007). There, AFT data indicate basement cooling below $105^{\circ}-125^{\circ} \mathrm{C}$ occurring between 240 and 220 Ma. A Cretaceous denudation phase can be inferred from the sedimentary record of the Prydz Bay offshore the Vestfold Hills.
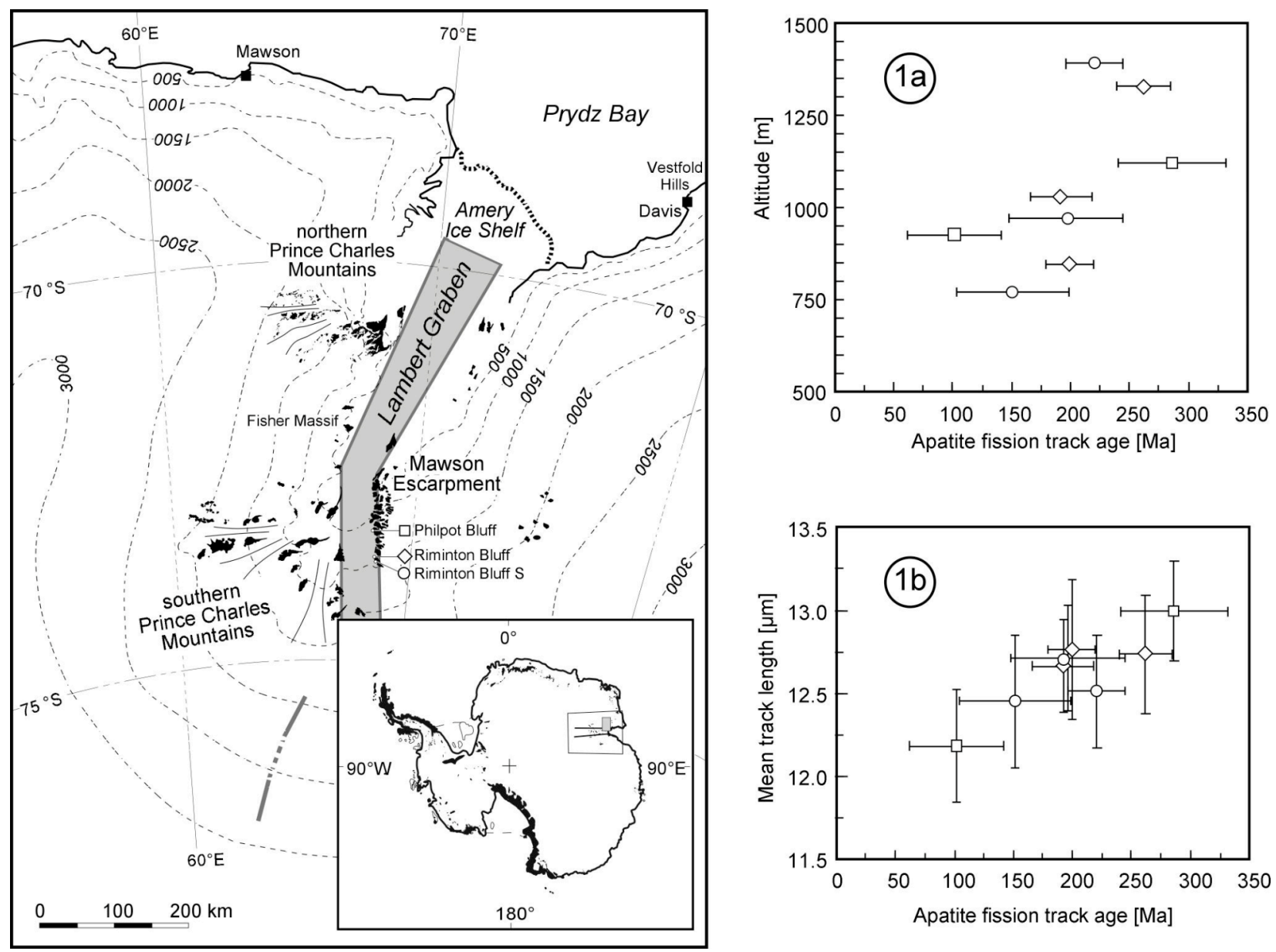

Figure 1. Location map of the Lambert Graben region/ East Antarctica (after Fedorov et al., 1982). Plots on the right show the apatite fission track ages versus sample elevation (a), and the relation between apatite fission track ages and mean track lengths (b) for the sample profiles from the southern Mawson Escarpment. Errors are plotted as $\pm 2 \sigma$. The sample symbols are: diamonds, Riminton Bluff; circles, Riminton Bluff S; squares, Philpot Bluff. 


\section{Apatite fission track results and thermal history reconstruction}

AFT data from three vertical profiles from the southern Mawson Escarpment are listed in Table 1 (linked plate) and illustrated in Figs. 1 and 3 (linked plate). The AFT ages obtained from eight samples from the southern end of Riminton Bluff, Riminton Bluff 8 $\mathrm{km}$ further north, and Philpot Bluff $(26 \mathrm{~km}$ north of Riminton Bluff S) range from $102 \pm 20$ to $287 \pm 23 \mathrm{Ma}$, and are thus considerably younger than the inferred Archean ages of the host rocks, and also younger than the last potential metamorphic overprint during the PanAfrican orogeny $(\sim 500 \mathrm{Ma})$. They are in the range of AFT ages reported from the northern PCM and Prydz Bay (Arne et al. 1993; Arne, 1994; Lisker et al., 2003: 100-350 Ma). Although the ages of each of the three vertical profiles correlate with topographic altitudes between 770 and $1390 \mathrm{~m}$, the regression varies significantly (Fig. 1a), and no age trend can be observed along the Mawson Escarpment. All sample ages but one (GC715-8: 62\%) fail the $\chi^{2}$ test with low probabilities $<5 \%$, indicating that the grains within each sample belong to more than one age population (Galbraith, 1983).

The mean track lengths of the eight samples vary relatively little from 12.2 to $13.0 \mu \mathrm{m}$ with standard deviations between 2.2 and $1.4 \mu \mathrm{m}$ (Table 1/ linked plate). In contrast to the diffuse age-elevation relationship, there is a tight correlation between AFT ages and length distribution (Fig. 1b), representing the old branch of a boomerang pattern (cf. Green, 1986). Such a pattern, combined with the correlation of the ages with altitude, the wide spreads of the single grain ages, the systematic shift of the bias within the track length histograms (Fig. 3/ linked plate), and the low $\mathrm{P}\left(\chi^{2}\right)$ probabilities, suggests initial cooling below $110^{\circ} \mathrm{C}$ followed by an extended period of thermal annealing, and a later, discrete period of accelerated cooling from a thermal maximum below $110^{\circ} \mathrm{C}$ (for interpretation of cooling patterns cf. Gleadow et al., 1986, 2002; Green et al., 1989). Thermal history modeling of the Mawson Escarpment AFT data (modeling details in Footnote 3 below Table 1) indeed reveals concordant cooling paths for all samples, comprising two cooling stages. The samples from the southern Mawson Escarpment cooled slowly through temperatures of $60^{\circ}-110^{\circ} \mathrm{C}$ (i.e., the apatite partial annealing zone: PAZ; Wagner, 1972) from Late Carboniferous to Early Jurassic times. Geological constraints (the presence of sedimentary deposits in the northern PCM and Prydz Bay) place the sampled rocks close to the surface during the TriassicJurassic. Subsequently, the rock column experienced reheating to maximum paleotemperatures between $76^{\circ} \pm 3^{\circ} \mathrm{C}$ and $96^{\circ} \pm 3^{\circ} \mathrm{C}$, and rapid final cooling commenced at $64 \pm 6 \mathrm{Ma}( \pm 2 \sigma)$. Denudational cooling to surface temperatures must have ceased during the earliest Cenozoic when the East Antarctic Erosion surface was established, but some climatic cooling in the order of $20^{\circ}-30^{\circ} \mathrm{C}$ (e.g., Barron et al., 1994) occurred since the onset of the permanent glaciation of East Antarctica in the Oligocene.

Usually, a vertical profile of maximum paleotemperatures derived from AFT data allows to estimate the paleogeothermal gradient at the time of maximum and/ or peak temperatures. However, this estimate is not warranted in this study since the misfit of observed and modeled track length standard deviation of three samples (Table 1), the not thoroughly linear regression of the paleotemperature profiles, and the limited maximum vertical separation within each profile of only $\sim 600 \mathrm{~m}$ likely introduces too much uncertainty into any robust paleogeothermal gradient calculation. Nevertheless, the regression of the maximum paleotemperatures modeled here versus altitude is best described by a Late Cretaceous-Paleocene geothermal gradient between $20^{\circ}$ and $30^{\circ} \mathrm{C}$ as obtained from the northern PCM (Lisker et al., 2003).

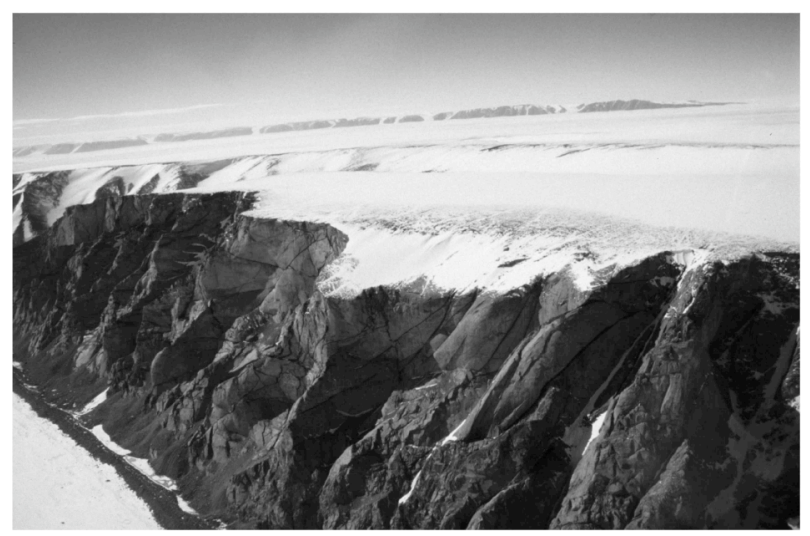

Figure 2. View on the East Antarctic Erosion Surface on the southern Mawson Escarpment.

\section{Discussion}

In general, minor and slow late CarboniferousTriassic cooling and much more rapid Late Cretaceous/ Paleocene cooling may have been caused by either the decay of heat added to the upper crust following dyke emplacement, and/ or denudation. However, radiometric dating and field relations indicate that the various igneous dykes cropping out within the Mawson Escarpment are exclusively of Precambrian age (e.g., Mikhalsky et al., 2001), and there is no evidence of any later hydrothermal or significant tectonic activity.

The Phanerozoic development of the southern Mawson Escarpment can only be understood when the thermal history obtained in this study is compared with earlier AFT work from the Lambert Graben (Arne, 1994; Lisker et al., 2003, 2007) and with the stratigraphic information from the northern PCM and Prydz Bay as the offshore continuation of the Lambert Graben. 
Amery Group outcrops of the Beaver Lake/ northern PCM and drill cores recovered from ODP Legs 119 and 188 within Prydz Bay combined with geophysical data reveal that the infill of the northern Lambert Graben comprises at least two kilometres of Permo-Triassic sediments (e.g., Webb \& Fielding, 1993; Barron et al. 1991; O'Brien et al., 2001). Both the continental Amery Group and the Paleozoic red bed sediments of Prydz Bay were deposited in an actively subsiding basin where rapid uplift, erosion, and deposition preserved their immature composition (e.g., Turner, 1991; Webb \& Fielding, 1993). A similarly thick upper Cretaceous sedimentary sequence is reported from Prydz Bay (Turner \& Padley, 1991) and can be envisaged in the Lambert Graben from the geophysical record (e.g., Fedorov et al., 1982). Kinematic indications obtained from the northern PCM (Boger \& Wilson, 2003) and geophysical data from Prydz Bay (Stagg, 1985) indicate that also the Cretaceous sedimentation was triggered tectonically.

Such a coincidence of the two depositional episodes with coeval cooling stages of the adjacent basement, and the -both in time and amount- regionally consistent style of cooling of the present graben shoulders for each phase clearly exclude the existence of a large, flat and homogeneous intracontinental basin. Instead, the observed pattern refers to denudational unloading of the graben shoulder and isostatic response due to rifting. Cooling of the southern Mawson Escarpment commenced at least in the Late Carboniferous, and therefore predates the onset of rifting as shown by the stratigraphic position of the Amery Group. However, this timing is in excellent agreement with the sedimentation of the Talchir tillites of the Indian Mahanadi Graben that is supposed to represent the continuation of the Lambert Graben (Veevers \& Tewari, 1995; Lisker, 2004). The respective amount of Carboniferous - Jurassic cooling must have been between $30^{\circ} \mathrm{C}$ (difference between higher $\mathrm{PAZ}$ temperature of $110^{\circ} \mathrm{C}$ and lowermost maximum paleotemperature of $\sim 76^{\circ} \pm 3^{\circ} \mathrm{C}$ ) and $>100^{\circ} \mathrm{C}$ (difference between higher temperature limit of the PAZ and surface temperature).

A tighter constraint of the amount of cooling can be inferred when comparing the low long-term cooling rate of $<1^{\circ} \mathrm{C} \mathrm{my}^{-1}$ between Carboniferous and Jurassic times with almost instantaneous Late Cretaceous/ Paleocene cooling of similar magnitude. This difference in the cooling/ erosion rate is hardly related to the tectonic setting that is similar for both stages. Nor does it refer to any specific climatic situation considering the broad variation from Carboniferous glacial conditions to a moderate to warm Permo-Triassic climate. We rather suggest a strong lithological contrast to be responsible for the change of the erosion rate. Recent studies from Indian cratons juxtaposed to East Antarctica demonstrate that Archean metamorphic basement often is extremely weathering resistant (e.g., Gunnell \& Louchet, 2000), and even major brittle tectonic structures tend to have very low long-term surface erosion rates of a magnitude as reported here (e.g., Von Blanckenburg et al., 2004: 2-11 m/m.y.). Taking into account the late Paleozoic - early Mesozoic erosion behavior of the basement, a Late Cretaceous/ Paleocene cooling rate of $\sim 10^{\circ} \mathrm{C} \mathrm{my}^{-1}$ is not plausible for these rocks. Instead, this sudden increase of cooling/ erosion requests the presence of a loosely consolidated Jurassic - Cretaceous sedimentary cover on the present erosion surface that was stripped away in a very short time. This overburden was removed, and the paleosurface on the weathering-resistant metamorphic basement was reexposed as early as $\sim 55 \mathrm{Ma}$ as indicated by the effusion of volcanic rocks (Wellmann \& Tingey, 1981). Then, denudation decelerated again until the surface was sealed by the East Antarctic Ice Shield from the Oligocene onwards.

When neglecting any climatic influence, the formation of a regional erosion surface during the Jurassic suggested here allows to estimate the amount of cooling during the first cooling/ erosion stage to $\sim 100^{\circ} \mathrm{C}$. For a geothermal gradient of $20^{\circ}-30^{\circ} \mathrm{C} \mathrm{km}^{-1}$ as determined for the western shoulder of the Lambert Graben during the Cretaceous (Lisker et al., 2003), the amount of denudation, obviously related to initial rifting and graben formation, can be calculated between 3.3 and $5 \mathrm{~km}$.

The second cooling/ denudation stage lasted significantly shorter, only some 10 my during Late Cretaceous and early Paleocene. Applying a paleogeothermal gradient between $20^{\circ}$ and $30^{\circ} \mathrm{Ckm}^{-1}$, cooling of $60^{\circ}-90^{\circ} \mathrm{C}$ refers to denudation between $\sim 2$ and $\sim 4.5 \mathrm{~km}$ of crust. This denudation was probably caused by tectonic activity associated with Gondwana breakup between Antarctica and India. Boger \& Wilson (2003) suggested that strike slip movements due to the rotation of India from Antarctica during the Cretaceous were responsible for the main rifting phase of the Lambert Graben.

\section{Conclusions}

Thermal history modeling of AFT data from the southern Mawson Escarpment revealed two cooling episodes interpreted in terms of minor and slow late Carboniferous-Triassic surface denudation and much more rapid Late Cretaceous/ Paleocene denudation. This denudation pattern has been obtained for all analyzed outcrops of both Lambert Graben shoulders. We therefore conclude either a homogeneous landscape evolution along and across this megastructure, or the Lambert Graben represents an alternating rift with the outcrop pattern being controlled by the position of the master fault. The latter interpretation is favored by new AFT data from the area around Fisher Massif (Lisker \& Brown, submitted). 
Moreover, our study validates the recognition that ancient continental landforms that have been produced, rejuvenated and buried over very long time spans usually cannot remain preserved sub-aerially, essentially intact, for hundreds of millions of years. Like most Gondwana surfaces presently exposed in India, Australia, southern and western Africa and even Antarctica (cf., Belton et al., 2004a; Lisker et al., 2006), the region covered by the East Antarctic Erosion Surface experienced a far more dynamic surface evolution than is implied in established models of long-term tectonic and geomorphic stability.

Acknowledgements. This study was funded by the ASAC projects 528 and 1/29 (C.J.W.) and supported by the Deutsche Forschungsgemeinschaft (F.L.: DFG project LI 745/7-2). F.L. and C.J.W. are very indebted to the Bundesanstalt für Geowissenschaften und Rohstoffe and the Australian Antarctic Division for the invitation to participate in the PCMEGA expedition. We are very grateful to Barbara Ventura for valuable comments.

\section{References}

Arne, D.C., Kelly, P.R., Brown, R.W., and Gleadow, A.J.W. (1993), Reconnaissance apatite fission-track data from the East Antarctic Shield, in Gondwana Eight: assembly, evolution and dispersal, edited by R.H. Findlay, R. Unrug, M.R. Banks and J.J. Veevers, pp. 605-611, Balkema, Rotterdam.

Arne, D.C. (1994), Phanerozoic exhumation history of northern Prince Charles Mountains (East Antarctica), Antarctic Science, 6(1), 69-84.

Barron, J.A., et al. (1991), Proceedings of the Ocean Drilling Program, Kerguelen Plateau-Prydz Basin; covering Leg 119 of the cruises of the drilling vessel JOIDES Resolution, Port Louis, Mauritius to Fremantle, Australia, sites 736-746, 14 December 1987-20 February 1988. Proceedings of the Ocean Drilling Program, Scientific Results., 119. Texas A \& M University, Ocean Drilling Program, College Station, TX, United States, 1003 pp.

Barron, E.J., Fawcett, P.J., Pollard, D., and Thompson, S.L. (1994), Model simulations of Cretaceous climates; the role of geography and carbon dioxide, in Palaeoclimates and their modelling; with special reference to the Mesozoic era, edited by J.R.L. Allen, B.J. Hoskins, B.W. Sellwood, R.A. Spicer, and P.J. Valdes, pp. 99-108, Chapman $\&$ Hall, London, United Kingdom.

Belton, D.X., Brown, R.W., Kohn, B.P., Fink, D., and Farley, K.A. (2004a), Quantitative resolution of the debate over antiquity of the central Australian landscape: implications for the tectonic and geomorphic stability of cratonic interiors, Earth and Planetary Science Letters, 219(1-2), 21-34.

Belton, D.X., Kohn, B.P., and Gleadow, A.J.W. (2004b), Extracting track age spectra from raw FT data - a method of establishing the "cooling onset age" and event timing in natural samples, 10th International Conference on Fission Track Dating and Thermochronology, Amsterdam, pp. DVL-06-P.

Boger, S.D., et al. (2002), Pan-African intraplate deformation in the northern Prince Charles Mountains, East Antarctica, Earth and Planetary Science Letters, 195(3-4), 195-210.

Boger, S.D., and Wilson, C.J.L. (2003), Brittle faulting in the Prince Charles Mountains, East Antarctica: Cretaceous transtensional tectonics related to the break-up of Gondwana, Tectonophysics, 367(3-4), 173-186.

Dunkl, I., (2002), TRACKKEY: a Windows program for calculation and graphical presentation of fission track data, Computers and Geosciences, 28(1), 3-12.

Fedorov, L.V., Grikurov, G.E., Kurinin, R.G., and Masolov, V.N. (1982), Crustal structure of the Lambert Glacier area from geophysical data, in Antarctic Geoscience, edited by C. Craddock, pp. 931-936, University of Wisconsin Press, Madison.

Galbraith, R.F. (1983), Goodness-of-fit tests in fission track dating, Mathematical Geology, 15, 567-569.
Gallagher, K., and Sambridge, M.S. (1994), Genetic algorithms: A powerful tool for large-scale nonlinear optimization problems, Computers and Geosciences, 20, 1229-1236.

Gallagher, K. (1995), Evolving temperature histories from apatite fission-track data, Earth and Planetary Science Letters, 136, 421435.

Gleadow, A.J.W. (1981), Fission-track dating methods: what are the real alternatives?, Nuclear Tracks, 5, 3-14.

Gleadow, A.J.W., Duddy, I.R., Green, P.F., and Lovering, J. (1986), Confined fission track lengths in apatite: a diagnostic tool for thermal history analysis, Contrib. Mineral. Petrol., 94, 405-415.

Gleadow, A.J.W., Belton, D.X., Kohn, B.P., and Brown, R.W. (2002), Fission track dating of phosphate minerals and the thermochronology of apatite, in Phosphates; geochemical, geobiological, and materials importance, edited by M.J. Kohn, J. Rakovan, and J.M. Hughes, pp. 579-630, Reviews in Mineralogy and Geochemistry, Mineralogical Society of America and Geochemical Society, Washington, DC.

Green, P.F. (1981), A new look at statistics in fission-track dating. Nuclear Tracks, 5(1/2), 77-86.

Green, P.F. (1986), On the thermo-tectonic evolution of Northern England: evidence from fission track analysis, Geol. Mag., 123(5), 493-506.

Green, P.F., et al. (1989), Thermal annealing of fission tracks in apatite: 4 - Quantitative modelling techniques and extension to geological timescales, Chemical Geology (Isotope Geoscience Section), 79, 155-182.

Gunnell, Y., and Louchet, A. (2000), The influence of rock hardness and divergent weathering on the interpretation of apatite fission-track denudation rates - Evidence from charnockites in South India and Sri Lanka, Zeitschrift für Geomorphologie, 44(1), 33-57.

Hurford, A.J., and Green, P.F. (1983), The zeta age calibration of fission-track dating, Isotope Geoscience, 1, 285-317.

Laslett, G.M., Kendall, W.S., Gleadow, A.J.W., and Duddy, I.R. (1982), Bias in measurement of fission-track length distributions, Nuclear Tracks, 6(2/3), 79-85.

Laslett, G.M., Green, P.F., Duddy, I.R., and Gleadow, A.J.W. (1987), Thermal annealing of fission tracks in apatite 2. A Quantitative Analysis, Chemical Geology (Isotope Geoscience Section), 65, 1-13. Lisker, F., Brown, R., and Fabel, D. (2003), Denudational and thermal history along a transect across the Lambert Graben, northern Prince Charles Mountains, Antarctica derived from apatite fission track thermochronology, Tectonics, 22(5), 1055, doi:10.1029/2002TC001477.

Lisker, F. (2004) The evolution of the geothermal gradient from Lambert Graben and Mahanadi Basin - A contribution to the IndoAntarctic Rift debate, Gondwana Research, 7(2), 363-373.

Lisker, F., Läufer, A., Rossetti, F., Olesch, M., and Schäfer, T. (2006), The Transantarctic Beacon Basin: New insights from fission track data and structural data from the USARP Mountains and adjacent areas (northern Victoria Land, Antarctica), Basin Research, 18(4), $315-340$

Lisker, F., Wilson, C.J.L., and Gibson, H.J. (2007), Evolution of the Vestfold Hills (East Antarctica) between Lambert rifting and Gondwana breakup; evidence from apatite fission track data, Antarctic Science, 19(1), 97-106.

Lisker, F., and Brown, R. (submitted), Segmentation and spatial variation of rifting of the Lambert Graben, Antarctica, Geol. Soc. Spec. Publ.

Mikhalsky, E.V., et al. (2001), Geology of the Prince Charles Mountains, Antarctica, AGSO Geoscience Australia Bulletin, 247, AGSO, Canberra.

O’Brien, P.E., Cooper, A.K., Richter, C. and al., 2001. Leg 188 summary: Prydz Bay - Cooperation Sea, Antarctica. Proc. ODP, Init. Reports, 188. Ocean Drilling Program, College Station TX, 65 pp.

Sheraton, J.W. (1984), Chemical changes associated with high-grade metamorphism of mafic rocks in the East Antarctic Shield, Chemical Geology, 47(1-2), 135-157.

Smith, M.J., and Leigh-Jones, P. (1985), An automated microscope scanning stage for fission-track dating, Nuclear Tracks, 10(3), 395400 . 
Stagg, H.M.J. (1985), The structure and origin of Prydz Bay and MacRobertson Shelf, East Antarctica, Tectonophysics, 114(1-4), 315-340.

Turner, B.R., and Padley, D. (1991), Lower Cretaceous coal-bearing sediments from Prydz Bay, East Antarctica, Proceedings of the Ocean Drilling Program, Scientific Results, 119, 57-60.

Turner, B.R. (1991), Depositional environment and petrography of preglacial continental sediments from Hole 740A, Prydz Bay, East Antarctica, Proceedings of the Ocean Drilling Program, Scientific Results, 119, 45-55.

Veevers, J.J., and Tewari, R.C. (1995), Gondwana master basin of Peninsular India between Tethys and the interior of the Gondwanaland province of Pangea, Geological Society of America Memoir, 187, 1-72.
Von Blanckenburg, F., Hewawasam, T., and Kubik, P.W. (2004), Cosmogenic nuclide evidence for low weathering and denudation in the wet, tropical highlands of Sri Lanka, Journal of Geophysical Research, B109: F03008, doi:10.1029/2003JF000049.

Wagner, G.A. (1972), The geological interpretation of fission track ages, Trans. Am. Nucl. Soc., 15, 117

Webb, J.A., and Fielding, C.R. (1993), Permo-Triassic sedimentation within the Lambert Graben, northern Prince Charles Mountains, East Antarctica, in Gondwana Eight: assembly, evolution and dispersal, edited by R.H. Findlay, R. Unrug, M.R. Banks, and J.J. Veevers, pp. 357-369, Balkema, Rotterdam.

Wellman, P., and Tingey, R.J. (1981), Glaciation, erosion and uplift over part of East Antarctica, Nature, 291(5811), 142-144. 